\title{
HOW FOREIGN OF A COUNTRY IS THE PAST? COLONIAL ARCHIVES, CUSTOMARY LAW AND LAND TRANSACTIONS IN GHANA
}

\author{
RALUCA PERNEȘ 1
}

\begin{abstract}
This paper looks at a set of documents produced in the early 1950s in the Gold Coast to establish land boundaries in a region and to contribute to the crystallization of customary law for future reference and use. The material is placed in a longer historical flow and seen as one of the results of transformations in the metropole, in the colony, and in their relationship over the first decades of the century, and as a significant landmark collection that has been used in land transactions ever since. The analysis pleads for treating the archives in an ethnographic and not just in an extractive manner (Stoler, 2002, 2009), suggesting that the making, the form, the authors' stances and the use of the documents can be useful supplementary tools in making sense of the already heavily edited representations of the past that we have access to. The focus on this particular archival material contributes to the discussions about the pitfalls of basing land management on, as Sally Falk Moore would put it, "customary" law.
\end{abstract}

Keywords: colonial ethnography, historical anthropology, archives, Ghana, Gold Coast

\section{Introduction: Colonial archives, history and ethnography}

Through the lens of anthropology, as well as through most other lenses, any attempt to make sense of the present without looking into the past could only range somewhere between naïve and misguided. But while the use of historical data and, increasingly after the 1990s, of the archives (Stoler, 2002) have joined the mainstream toolbox of the anthropologist, there is a long way to consensus as far as their epistemological standing is concerned. In researching the past, just as in researching the present, the search is for a tentative, not for an absolute truth. Yet, in theory, the present is out there for exploring in all its

${ }^{1}$ Independent researcher, email: rpernes@yahoo.com. 
complexity, while the past is already heavily edited. What do we make of what we have of it? This paper explores some of the tensions, contradictions, ruptures and continuities incorporated in the content of a set of historical documents, as well as in the circumstances of its production and of its later use. It investigates a particular sliver of colonial history, the area where "engagement with the uses and abuses of the past" (Stoler, 2002:89) is the most pervasive.

Historical documents are a specific form of representation of the past, that may be fragmentary and possibly at least partly inaccurate. Their first layer that comes to light is that of their actual content, and the major risk - that this will remain the only layer to be revealed. In the postcolonial context, there might be a temptation to necessarily frame the analysis in terms of the rupture between the colonial and the rest of history. Documents are in danger of being "invoked piecemeal and selectively to confirm the colonial invention of traditional practices or to underscore cultural claims" (Stoler, 2002:90), while their potential to be used as bona fide ethnographic material goes neglected.

Archival documents often present themselves as the voice and the position of states and their institutions in relation with their subjects and with the world those subjects inhabit. We have known for some time now that they are a lot more than that. Documents produced by a state, at home or in the colonies, do not just describe reality to the best of their authors' ability, through their particular viewpoint, whatever that may be. They bear the weight of an agenda. They are systematically and strongly biased towards instrumentalizing their insights for making the world legible, and thus governable (Scott, 1998). Official documents remain one of the main sources through which we can glimpse into "how colonizers in the nineteenth and twentieth centuries tried to make the categories through which they classified and surveilled their subjects" (Cooper and Stoler, 1997:4).

Over the last few decades, there is a widening circle of anthropologists trying to avoid the previous pitfalls of dealing with historical data and to move past these crucial, but crude stakes of the historical documents. One of the possible radical approaches is for the anthropologist to make their own alternative archive to give depth or challenge the perspective afforded by official papers, the way Jean and John Comaroff do for South Africa, where they look at "textual traces" in the shape of newspapers, novels, songs, or children's games (Comaroff and Comaroff, 1992). But when the archive remains the main object of the investigation, the anthropologist can still consciously move away from an extractive to an ethnographic use of it (Stoler, 2002, 2009), looking at the making, the form and the use of the archives; making sense of the positions of the individuals producing them, beyond the main agendas of their employers; treating the moment in time in which they are created as the product of previous history and generator of future history. 
Turning historical sources into the object of ethnographic research need not mean limiting the scope of their meaningfulness, from a piece that can make sense in the puzzle of global history to one that is relevant to a very particular set of circumstances. On the contrary, "[t]he phenomena we observe may be grounded in everyday human activity, yet such activity [...] is always involved in the making of wider structures and social movements" (Comaroff and Comaroff, 1992:32). Colonial history needs to be assembled from precisely this type of material, in which the metropole and the colony are present simultaneously (Cooper and Stoler, 1997), and which speaks to global structures as well as local specificities.

In what follows, I take the example of a set of data put together towards the very end of the colonial period in the Gold Coast, nowadays Ghana. These documents were produced under the provisions of the Land Boundaries Settlement Ordinance of 1950 and comprise interviews conducted with 184 witnesses (chiefs, family elders, land surveyors) in 1954 and the report of the settlement commissioner, finalized in 1955 and published in 1956. Their purpose is to identify the principles of land ownership and use and to outline the land boundaries of the Shai State, Ningo, and Prampram, an area of about 500 square miles in the south of Ghana, starting about $30 \mathrm{~km}$ east from the capital of Accra. ${ }^{2}$ The following year, in 1957, the Gold Coast was to become the first colony in West Africa to gain its independence from the British Empire, and the significance and use of these documents was to change completely. Nowadays, Ghana uses a system of legal pluralism, with land matters dealt with by traditional authorities under the principles of customary law, in its ethnic-based and often specifically local incarnations. The findings from the 1950s therefore still hold direct relevance.

In zooming in on these documents, I am interested in land policies and practices around the time of Independence, as generated by the tensions and conflicts, as well as the congruencies and continuities between the Empire and the colony, and as codified by the settlement commissioner and the witnesses. I aim to understand this particular configuration of land practices in the Gold Coast as a result of previous processes and a premise for future transformations, as well as an outcome of a meeting of the knowledge and intentions of individuals driven by their agendas. The archival text is not merely a source of information, but an object of research in itself.

\footnotetext{
2 I look at this set of archival material as part of a larger research into land tenure, allocation and use in a periurban area in Southern Ghana, part of the region covered by these documents. Throughout, I plead against the fetishization of tradition and attempt to understand the intensifying struggle for land in this particular context as a symptom of global processes, rather than solely as a consequence of postcolonial configurations of legal pluralism and modernity.
} 
RALUCA PERNEȘ

\section{Customary law in the Gold Coast under colonialism}

Throughout Africa, the formalization of colonialism ostensibly brought about very little change in terms of land management;

in both British and French colonies rural people were integrated into the colony through customary law, which provided them with rights to land and obligations to chiefs, who were empowered to make local bylaws (Amanor, 2008:131).

Needless to say, the label of "customary law" gives a semblance of homogeneity that covered then, as it covers now, an incredible array of different arrangements. Within this frame, the metropoles and the colonized too were bound to have various specific interests in land rights. These eventually catalysed interrogations, challenges to and transformations of local formulations of customary law at different scales and with different outcomes. Apart from the certainties of universal statutory laws, customary law continued to change, contained and controlled only at the level of semi-autonomous social fields (Falk Moore, 1986). Though it needs to be said that customary law must have been changing beforehand as well, the new configuration brought pressures of a different scale.

In the Gold Coast, the first attempt at systematic change came with the Crown Lands Bill of 1894, vesting waste land, forest land and minerals in the British Crown. The Bill was met with resistance by the elites of the colony, who were prompt to point out that "according to native ideas, there is no land without owners" (Sarbah, 2017:66). Large tracts of land were indeed not used, but according to this interpretation of customary law, that was not to say they did not come under the authority of any (collective) owners. The Bill was rescinded and in 1897, the Crown issued the Lands Bill. This preserved the Africans' settlers' rights but also introduced the practice of transmitting property rights in accordance with the English law, in parallel with customary law. Land certificates issued in this manner gave Europeans firm land titles and consequently security of tenure for their investments in the Gold Coast (K. Amanor, 1999; Lentz, 2013). Soon after, J.W. Sey, J.P Brown, J.E. Casely Hayford, and John Mensah Sarbah founded the Aborigines' Rights Protection Society (ARPS) to oppose the bill. The ARPS comprised the local elites, members of the commercial bourgeoisie and intellectuals, some of them of mixed EuropeanAfrican descent, most of them educated abroad and typically in London. Several of the prominent members were lawyers. In negotiating with the metropole, they combined accurate and appropriate arguments from the British law and interpretations of the local customary land laws, whereby the latter were 
looked at through the lens of the former. The ARPS manufactured a common denominator between the two legal systems, as the only device that could make the Gold Coast practices readable and intelligible, and most importantly legitimate, to the British. In 1898, the ARPS was ostensibly successful in its demands and the Lands Bill was rescinded. The British, however, labelled the "traditional" land tenure system as an obstacle to progress and recommended the gradual privatisation of lands (Lentz, 2013).

In any interaction between the metropole and the colony, there is a matter that reasserts its relevance, namely that of the articulation of a grammar of difference (Cooper and Stoler, 1997) between the two entities. But, as the example of the negotiations around the Lands Bill showed clearly, the premise of homogeneity within any of the two does not stand to empirical scrutiny, and neither does the radical difference between them. In terms of language, education, tools, categories, and occasionally even in terms of power and interest, the elites of the colony resemble more closely the business class in the metropole, than the popular classes of the colony. When resisting the actions of the metropole, they stand up for their own specific interests as entrepreneurs and players on the global market, and not for some generic interest of the weak at the margins of the empire. The categories of powerful and weak, of modern and traditional, are thus rendered fluid in the exercise of the interactions.

The clashes around land laws in this period did eventually result in the first codified version of customary land laws in the Gold Coast, the effects of which are still visible today.

The invented traditions of African societies whether invented by the Europeans or by Africans themselves in response - distorted the past but became in themselves realities through which a good deal of colonial encounter was expressed (Ranger, 1983:212).

Over the next half a century, the legal regime that regulated land ownership and use did not change, but, in both the metropole and the colony, events led to shifts in positions and practices.

In the Gold Coast, in this period, the cocoa economy continued to grow (Amin, 1973; Hill, 1997). Cocoa cultivation was atypical in the region as it was a large scale business initiated and managed by local farmers and entrepreneurs, which practically took on the form of a merchant capitalist enterprise. For the metropole, cocoa farms offered an unusual but welcome system of production without wage labour (Cooper, 1996), as long as it could eventually be incorporated into commercial networks regulated by the empire. Colonial administrators, however, did not interfere at all until the 1940s, when they stepped in to order 
cutting down the cocoa trees affected by the swollen shoot disease. Throughout this period, the constantly expanding cocoa belt in then Gold Coast welcomed new farmers. Most bought land collectively, through the organization of what they called "companies", in which members were allocated rights in lands. Others, hailing from the area, bought rights to family lands and organized in the form of an abusua, another type of group organization that can be mobilized for farming, based on extended family ties (Hill, 1997). In her comprehensive study of cocoa farming in the Gold Coast, Polly Hill (1997) shows that arrangements around lands sales and leases for cocoa cultivation were extremely intricate and variable, yet still attached to the spirit of what she herself calls, in between brackets, "traditional organisation". But most of the practices in the cocoa belt did not conform to the most popular tenets of customary law, especially because outright sales of lands were permissible and common.

The other major transformation in the colony, in first half of the $20^{\text {th }}$ century, was the growth of a class of salaried workers in the fields of industry, construction, transport, and mining, whose activity and cooperation was essential for the good run of the colony. Starting with the 1920s, these workers, who were perceived by the metropole as "tribal", became increasingly discontent with their labour conditions and wages and, at the same time with workers across other African colonies, repeatedly joined forms of social unrest. Throughout the 1930s, workers in the West Indies started striking. They were soon followed by the miners in Northern Rhodesia in 1935, a general strike in Mombasa and a dock strike in Dar es Salaam in 1939. Also in 1939, the Gold Coast saw the strike of the railway workers of Sekondi, who had already struck in 1918 and 1921. In 1941 the railway workers of Sekondi started another strike and were joined by other workers, including those in the main harbours at Takoradi and Accra. In 1942 workers in Nigeria and Kenya were also protesting and striking again. Throughout the $1940 \mathrm{~s}$, major strikes continued to occur across the continent, culminating in the Gold Coast railway and gold mine strikes of 1947 and the Accra riots of 1948 (Cooper, 1996).

It was only at the end of World War II that the metropole was prepared to revisit the categories in which it understood the fates of its subjects in the African colonies. By then, the British Empire had lost its Asian colonies and became even more reliant on Africa for the tropical commodities it needed. Development, welfare and good standards of living finally came to the top of the agenda for the colonies, with the assumption that they, too, could leave behind traditionalism and at least partly embrace modernization. This was not going to make good bedfellows with customary law.

In 1949, Charles Arden-Clarke took over the governorship of the Gold Coast in the aftermath of the Accra riots. By 1950, he had made substantial amendments to the ten year plan for the colony he had inherited from the 
previous administration. In 1951, following the elections under the new constitution, political leader and self-governance advocate Kwame Nkrumah went from imprisonment for instigating strike violence straight to the position of leader of government business under governor Arden Clarke. In 1952 he became the first prime minister of the Gold Coast. For this brief period, the Gold Coast was, for all intents and purposes, run by a colonial governor and a local leader. This represented an important shift in the relationship between the empire and its colonial subjects. While up to World War II the metropole had structured hierarchies that were variations on the relation between master and servant (Ranger 1983), and the colonized accepted or resisted them to different extents, this period marks the change of paradigm to a partnership where both associates envision a future where the colony will become independent of the empire.

In the interval between the two wars, the increasingly loud voices of the local intelligentsia had argued for changing the status of autochthonous forms of knowledge and social organisation, but they did so from an implicit assumption that this would take place in the frame of the empire. By the early 1950s, both the people of the Gold Coast and the British administrators had changed their minds about that assumption. Arden-Clarke and Nkrumah were cosmopolitan intellectuals and knowledgeable participants in the global political processes. Their debates about the present and the future of the Gold Coast were taking place on common terrain that was shaped, in Said's terms, by a cultural shift foreshadowing the political and economic processes. Native resistance to imperialism fed on metropolitan doubts about and opposition to the empire (Said, 1994).

\section{Priming the Gold Coast for independence. Research on customary law under the Stool Lands Boundaries Settlement Ordinance of 1950}

This was the context in which, during the early 1950s, land commissioners undertook the arduous task of mapping land boundaries across the colony. The British were ready to withdraw from the Gold Coast, but, as was the case with the other colonies, were aspiring to continue an economic relationship with it. For this to be feasible, the British needed to integrate a paradox: to affirm that land use by the locals in the colony was conducted based on African rules, while at the same time striving to incorporate those rules into structures so as to afford the possibility of conducting business in European structures. At the turn of the century, the local intelligentsia had been motivated to 
describe and codify local land tenure systems in terms of English law, playing down its Africanness; by the middle of the century, the British, in order to support their projects for the future, needed to both account for the specific Africanness of autochthonous land systems and to systematize them so as to permit their future development and co-optation into western-centred economic relations.

Many of the colonial administrators proceeded in earnest to amass information about land boundaries, a process that produced copious amounts of spectacularly contradictory descriptions representing interpretations and simplifications of local arguments, in themselves a product of on-going negotiation at the local level. The research and mapping that followed the Stool Lands Boundaries Settlement Ordinance of 1950 made up the basis of three types of documents: interview transcripts and maps; the findings published by the Ministry of Interior; and larger studies, based on fieldwork and documents including court records, that synthesize land tenure systems in the colony and put them in a comparative perspective. R.J.H. Pogucki, an assistant commissioner of lands, gathered his notes and interpretations in "Gold Coast Land Tenure", a four volume study published in 1950 focusing on the Northern Territories, the Adangme and the Ga. It is the most organized of the reports of the period. Pogucki (1955) stressed the gaps in knowledge that exist about several of the areas on which he reports. Nonetheless, like many of those doing similar work, he phrased his findings strictly in ethnic terms, smoothed over excessive variation by assimilating smaller ethnic groups to the larger ones in the area, and based his extensive study on a research of just seven months (Goody, 1958).

John Jackson acted as a lands commissioner in the last years of the colonial rule in the Gold Coast. Jackson had been a judge in the Nigerian High Court between 1935-45, and then a judge of the Gold Coast's Supreme Court from 1945 (Rathbone, 2000). In June 1954, he conducted 184 interviews with chiefs, land surveyors, family heads and clan representatives from the area between Shai Hills and Ningo, as a measure of the Stool Lands Boundaries Settlement Ordinance of 1950.

I decided to take a closer look at this material once I realized that those involved in land contestation in the area covered by it used it as one of their key pieces of evidence in courts of law. Traditional leaders, themselves legitimate repositories of oral histories under customary law, embraced and made use of the superior type of legitimacy granted by a document that had been codified in writing and had the backing of official institutions from decades previous. Technically, the information about land boundaries, tenure and allocation is contained in the final report and in separate lists of land boundaries coordinates. The interviews are the raw material on which these 
are based. Methodologically, I looked at these documents only as a first step for the factual information they contain. The purpose for which I used them, as is often the case with the anthropological gaze on the archive, is not the purpose for which they were designed. I delved into the interviews to investigate their relation with the report, without taking it for granted, and looked at the social implications and effects of this specific set of archival material.

I went to look for Commissioner Jackson's interviews and reports at the Public Records and Archives Administration Department (PRAAD) in Accra. The setting seemed befitting: a large, airy building with modernist architecture, sharing a carefully manicured compound with the History Museum, staffed by affable clerks who handled forms, demanded for documentation, and disappeared behind doors that must have hidden the yellowing mountains of paper of my imagination. I shouldn't have bothered. In the end, I became familiar with Jackson's interviews in the form of bounded piles of freshly photocopied paper, of which there were many in the region it documented. Gone was the half-risk, half-anticipation of the archive fever - pace Steedman (2002), rather than Derrida. There would be no dust inhaled during my forays into the stacks of documents, and therefore no induced febrile anxiety about unmanageable tasks within the confines of the archives' building; there would be no opportunity to face - or excuse to romanticize - the occupational hazards that come with working in the archives (Steedman, 2002). Away from the confines of the purpose of their author, the documents took on a life of their own postcolonialism.

My request at the Archives was typical, I learned, and treated as a standard order. The situation was echoed in the other coastal areas, where litigants in cases concerning land ownership - usually tied to the right of first arrival/conquest - jostled each other to persuade the courts to (re)codify their versions of the (historical) truth, which were partly expected to be tied to this artefact of colonial administration on its last legs. Archival documents and rare, obscure legal anthropology texts were certainly not the province of the historian or the social scientist in these circles.

Whether confined to the safety of the archive our out in the world, colonial documents - all documents, for that matter - do not have the power to conjure the truth. The knowledge about the circumstances of their production can only ever be fractional, and our engagement with them is necessarily politically tinted by our own histories and positions in the world. We can only have versions of and understandings of truths. Yet there is a lot to be learnt from these documents about the nature of imperial rule, its agents, and its subjects (Stoler 2009). 
Declaratively, the task of the land commissioners was to document the land boundaries in their allocated areas. In following this objective, they were engaging in the colony in one of the typical exercises in rationalization and standardization that were the trademark of modern European statecraft (Scott 1998). They needed to reach common denominators, to simplify, to pick and choose and cull and eventually formulate an administrative instrument amenable to use by the state. Land boundaries are a but a minuscule aspect of the lives of people and their relationships with their ancestors, kin, communities, ethnic groups, neighbours, as well as colonial administrators and institutions. To speak about them in isolation is to sequester a sliver of reality and make claims to it making sense on its own; moreover, to very likely embrace the fact that the privileged public that finds it intelligible is the administrative apparatus itself.

The anticipated output was to be not just a map of land boundaries in the delineated region, but rather a "map of legibility" (Scott 1998). By the fact of being committed to paper as official documents, these decontextualized fragments of reality were endowed with the ability to further transform reality through the power vested in them by the authorities. And while oversimplifying reality is always a daunting task, state-making in the colony comes with the compounded difficulty of reducing to the perceived bare bones a complexity that is narrated through the filters of language and cultural difference.

\section{Traditional leaders on Adangbe law and custom}

The interviews are conducted by Jackson as part of a legal investigation and meant to substantiate the systematization and conclusions he would later assemble in a report. But they would eventually serve, as we will see later, as a source of factual information and they also prove to be rich in ethnographic detail. I take a closer look at the examination and cross-examinations of one of Jackson's informants to give a sense of the type of material the commissioner gathered, in all its complexity, self-assuredness and imprecision.

The first witness interviewed by Jackson after hearing the statements of the land surveyors is Okanta Obrentri II. The identification data logged for this interview tells us that he is a male, speaking Twi, and is the Benkumhene ${ }^{3}$

\footnotetext{
${ }^{3}$ In the Akan chieftaincy tradition, the Benkumhene is one of the subchief positions describing military flanks, namely the one who holds the left flank of the army's formation. It is not clear if the interviewee uses the Akan term because he is speaking Twi or because he wants to make the position intelligible to the commissioner.
} 
of Lartey ${ }^{4}$ of the Akwapim State, enstooled about one and a half years previously. One can not really evoke the atmosphere in which these conversations took place. We have no knowledge of the information the witnesses were given beforehand about the purpose of their statements, no idea how accurate the transcripts of the interviews were, no clue as to the competence of the translators. We jump straight into the heart of the matter with the first question: "You claim the land which Shai occupy as being Akwapim State Land?" The interviewer is clearly informed in advance of the positions the witnesses are going to take, and they rarely disappoint. "How did the Shais come to settle on this land?", the second question, prompts a typical answer from the toolbox of land politics. It is a story that purports to be of first settlement, widely recognized as the basis for land claims already in the ARPS descriptions of half a century earlier. It is, for all intents and purposes, a founding myth.

The chief describes the journey of the Larteys from Bonny in Nigeria to Labadi, now incorporated in the south of Accra. Here, they left behind the Labadis and moved on to "the hills of the monkeys" that are the Shai Hills. From this spot, they wandered off for lack of water and finally settled in the Akwapim mountains, where water was sufficient. The thread of the story is interrupted by the commissioner trying to pinpoint a detail: "What do you call your race?" "The Les." Then, perhaps counter intuitively for a story of first settlement, we find out that the Larteys ran into some people on the Shai Hills. And we do not find out more, since the story is cut short by another precise question: was there, at the time, an Omanhin ${ }^{5}$ of Akwapim? "I cannot say, as they were not then in Akwapim", the chief retorts. It is a classical misunderstanding, repeated many times over the pages of transcripts. The commissioner is supposedly asking the chief whether his own ethnic group had, at the time of the story, a hierarchical organisation ruled by an Omanhene. The chief's defensive repartee most likely refers to the Akan Akwapims, of which the Guan Lartey Akwapims, his own group, are not a part. He takes the question as a sign of the interviewer tricking him into admitting that the Akan Akwapims had already settled in the area at the time of his story. He is fully unaware of having already admitted there were other people living in the area at the time, thus potentially voiding their right of first arrival. Also, the chief is not having it with the interruptions and continues unperturbed with his tale. When the hunters reported the presence of some people in the hills, the Lartey chief Asiedu Kokor sent one of his subchiefs to find out about them. The strangers, handily

\footnotetext{
${ }^{4}$ Lartey, also spelled Larteh, is a sub-group of the Guan speaking Akwapims. There is also an Akan (Twi speaking) branch of the Akwapim group.

5 The Omanhin or Omanhene is the king of an ethnic group. The word is often translated into English as "paramount chief".
} 
enough for some people just wandering about in the Shai Hills, could send over five of their elders. The elders, named as Doku Yumu, Duku Churu, Tettey Kwa, Mlayo, and Tettey Fiakpa, ostensibly explained they had moved to the hills in the aftermath of tribal wars and they wanted to be under the Chief of Lartey for protection in case of attacks. The Lartey chief and the elders later met to drink fetish "to ensure fidelity". The Shais were given rights to cultivate and enjoy the proceeds of the farms. "What happened in 1892?" There are time marks the interviewee needs to check so as to allow for the greater narrative in the mind of the interviewer. In 1892, the Shais were removed from the hills by Government soldiers. The Larteys allocated them new lands at the foot of the hills, where they could be close to the Larteys and out of the way of the soldiers.

After a brief talk about boundaries and founders of specific villages, the discussion moves on to another group, the Ningos, who apparently were attracted to the area by a newly established market and ended up begging for land from the Larteys. Some of them bought land, but the chief admits to not having any documentary evidence of the sales and to not having been present at any of the transactions, although he is "between 53 and 54" years old. Later in his statements, he also returns to withdraw or rectify some of the facts he listed, based on the information gathered from his elders in between hearings.

The type of information gathered from every individual witness is extremely intricate and, by virtue of the topics they are discussing, they are all implicitly invited to be unreliable narrators. There is no evidence to back up any of their reports about the details of events from centuries ago. The other witnesses often have wildly different stories about the same lands. And where two or more happen to agree, there is still a chance they will have a completely different interpretation of the events. There is also a high risk to suspect that, where stories of ethnic groups, migrations, wars or first settlements are in concordance, this only happens because the groups with opposite interests can tell they can better stake their claims when they refer to a common frame of events. If there is a message driven home forcefully by such interviews, it is that the very premise of customary law for land management is inherently shaky.

\section{Jackson's report}

The outcome of Jackson's effort was a set of findings regarding the stool lands boundaries settlement for Shai State, Ningo and Prampram, published in an extraordinary issue of the Gold Coast Gazette on the $3^{\text {rd }}$ of August 1956. The purpose of the text is legal, and the language and type of data it mobilizes 
often show it. Nonetheless, this is no dry inventory of information. Jackson's report is based on a lot more than the interviews and the fieldwork conducted to establish the land boundaries. He reviews historical and legal literature. $\mathrm{He}$ delves into linguistic explorations, is occasionally generous with ethnographic detail, ventures into comparisons (especially with Nigeria) and pieces together local histories.

The scope of the report is to give an account of customary law as practiced by the Adangbe living in the area. The main premise of customary law as understood in this context is that things are done the way they have previously (always?) been done, based on initial rights in land gained through first settlement. At this time, there seems to be a consensus between the commissioner and those he interviews as to the decisiveness of first settlement, although it is likely it has been reached over the course of the colonial period and possibly influenced by the categories laid down by the ARPS around the turn of the century. Nonetheless, as apparent in the interviews themselves, sometimes the same rights are claimed by virtue of conquest. Perhaps more significantly, also as seen in the interviews, it is not clear what qualifies as first settlement, and several of the historical accounts of the smaller ethnic groups researched by Jackson describe placing roots as "first settlers" in areas that were already inhabited.

There are several such lines of tension running through this analysis that might have been apparent to its author as well. Customary law is, by definition, based on practices in the past. As Jackson states,

to understand the problem it is essential to give careful attention to ancient history, to the alliances, friendships and enmities of the several tribes, or even clans within a tribe, which are so long remembered, and which tend to cloud and prejudice an accurate assessment of each communities' rights (Jackson, 1956:1037).

Yet, the stakes of the exercise are not related to the past, but to establishing current guidelines for future use: "The scope of the enquiry is to determine what interest in land is vested in the Shai, Prampram and Ningo Stools, and not what may have been vested at some remote point in history" (Jackson, 1956:1041). But, potentially, every right in land at any given time can become subject to contestation through questioning that ancient history.

In a larger perspective, this is part of a wider tension inherent to Jackson's work. Over several months of fieldwork, examination of witnesses and investigation of historical sources, he gathers and aims to take into account an impressive amount of incredibly detailed information, painting incomplete, unreliable and often contradictory representations of customary 
law. But what he feels he needs to produce based on all the tiny details is a set of clear cut, general rules. Jackson is well versed in this exercise and looks at Adangbe customary law comparatively, seeing similarities with the practices of the larger ethnic groups in the colony, as well as with other British West African colonies:

in principle there is little by way of distinction between the Akan and the Adangbe law, indeed from some 25 years experience in land litigation in the Southern Provinces of Nigeria and more particularly in the Western Provinces there the principles regulating land tenure are different in form rather than in substance from those prevailing in the Gold Coast (Jackson, 1956:1048).

In the eyes of the commissioner, there is no doubt that general principles are more worthy than minute ethnographic details; in fact, the latter might be dangerous or destructive.

It is all a question of form or even verbiage, rather than substance, and it appears to me to be academic and unreal to try to dissect and tear away the flesh in order to examine microscopically the bone structure. In law one must bring one's facts within the ambit of broad and guiding principles and be able to discuss the substance rather than the form, without which there can be no orderly social progress (Jackson, 1956:1048).

Here, Jackson's agenda is transparent, as is the very purpose of the Land boundaries ordinance that he is implementing - in this context, researching customary law is not some gratuitous historical exercise; it is the necessary premise for a more efficient management of land contestation and conflict, which would amount to a form of modernisation of the land tenure system in the colony that can facilitate smoother dealings with the European businesses. Perhaps along with the metropole, Jackson's view of the Gold Coast and its possibilities in relation to the western world has switched from the crude dichotomy of superiority - inferiority to a slightly less limiting evolutionist perspective. According to this, his systematization contributes to making Gold Coast land practices more legible (Scott, 1998), a prerequisite, here as well as in the metropole, for the advancement of a modern state.

Methodologically, the report fails to resolve the main problem with customary law: the substance, that is, the guiding principles, can only be implemented if there is agreement about the form, which is made up of the details of the first settlement or conquest histories and of the use and allocation practices of the particular groups. Jackson earnestly tries to figure out the "truth" 
about these details, using the best available practice in his profession. He incorporates the relevant information in all the available historical sources: Barbot's "Description of the coasts of North and South Guinea" (1732), Bossman's "Description of the Gold Coast" (1705), Reindorf's "History of the Gold Coast and Asante" (1889) and Ward's "History of the Gold Coast" (1948). As stated by Jackson himself, the first two were produced for practical interests during the slave trade; the third is based on interviews conducted by a missionary, while the fourth is based solely on secondary sources. The main failure of these previous histories, Jackson feels, is that they risk including errors because of lack of cross-examination. So, in conducting his own research, he relies heavily on cross-examination. Nonetheless, the interviews display vast amounts of contradictions and disagreements that he tries to smooth over. Jackson feeds the fantasy that, if only one assembles the ultimate assessment, based on the most accurate and complete data available, this can become a point of reference to be used without contestation in the future.

Alas, it was not to be. Jackson's report came out a year before Independence and so had very limited opportunity to be used for the direct purpose for which it was designed. Yet, it never became an obsolescent trace of colonial administration. It is in fact very likely that, given the transformations that had taken place in the relationship between the Gold Coast and the metropole in the previous years, the colonial administrators themselves aimed for the reports of this ordinance to be used by the eventually independent colonies in their future administrations and in their dealings with the British businesses. Indeed, the report and the data it is based on became a point of reference and, as shown before, is still being widely used today in the region. The manner in which this happens, however, would have disheartened Jackson.

Most of the lands in the area in which he worked became increasingly desirable and valuable over next few decades. The state stepped in to acquire land for subsidized farming; wealthy entrepreneurs developed high profile projects, such as the campus of a large private university; real estate developers came in to build several gated communities with expensive family homes; from both Tema and Accra, people moved in and assembled new communities; pushed away from the lands in the capital, exotic vegetable producers came over; part of the Shai Hills was turned into a nature reserve, while the beaches became interesting for small touristic businesses. Development was extremely unequal and some areas became wildly sought after. In this context, contestation over land continued and became more and more intense. Clans and families competed for the right to lease out the land, many plots were sold multiple times and several major cases got stuck in courts of law for years. 
Jackson's material did not end up gathering dust in some corner of the Archives, but got bounded and printed as a standard order for all those involved in land cases, of which there are several. It was used equally confidently by opposing parties, which means that the commissioner's aspiration of establishing some ground truths ultimately proved futile. It is the ambiguities and the contradictions of his witnesses that are still used as evidence in contemporary cases, rather than the substance he saw in them. The rights in these lands are still not settled definitively. There is no way to definitively establish some unquestionable truth about events that took place hundreds of years ago, of which there is little proof and no material evidence. Without them, customary law is doomed to remain - and in fact has so far remained - the playground of endless debate and contestation by those who feel entitled to rights in lands, and by those who have the resources and aplomb to stake claims in lands even though they might not believe they are rightfully entitled to them. As Jackson himself put it some six decades ago, showing self-awareness and vulnerability "Are the persons interested in these lands just untruthful, or is it that they do not know [...]? In my view, there is an element of both" (Jackson, 1956:1052).

\section{Concluding remarks}

In a rush for analytic and symbolic reparations in the postcolonial period, one might find it easy to label a work such as Jackson's as intrusive, oversimplifying, presumptuous and perhaps even condescending of the people he worked with, considering he aimed to grasp some truth beyond what the people themselves had access to. It is facile to see the commissioner himself as simply a tool of colonialism, instrumentalizing a set of information to contribute to the crafting and reinforcement of a relationship of domination and exploitation. And we do need remain vigilant and look at the situation first and foremost through that lens. After all, it is easy to see the outcome of the Land Boundaries Ordinance was a standard example of "the processes by which disparate, even divisive discourses were fused into a consistent ideology" (Comaroff and Comaroff, 1992:35). But, as illustrated by the mobilization of the Gold Coast elite since the turn of the century and by the colony's workers throughout the first half of the century, they were perfectly capable to fuse fragments and articulate ideological positions of their own. In this context, the researcher needs "to attend more directly to the tendency of colonial regimes to draw a stark dichotomy of colonizer and colonized without themselves falling into such a Manichaean conception" (Cooper and Stoler, 1997:3). 
In itself, the production of these interview transcripts and report does not make them into a part of the hegemonic discourse. The Stool Lands Boundaries Settlement Ordinance was repealed a few years after Independence, in 1962. But once produced, official documents take on a life of their own. The Ordinance repealed, they had ceased to be a support on which power relations were inscribed and turned into technologies of rule themselves (Stoler, 2009). Maybe less intuitively, they also turned into instruments of disorder and contestation and into tools that are accessible and are used, more or less successfully, by the weak and the powerful alike, in the postcolonial configurations.

This is a story of a particular episode in the discussion of customary law as applied to land management. It is perhaps more significant than others because, by taking place in the very last moments of colonialism, it helps blur any certainties related to the agenda of the metropole and or to the powerlessness of the colonized. It is one of many windows into the intricacies of customary law at work, but shows that, regardless of the moment in time we choose to investigate the issue, there is a fundamental problem that means customary law can not work efficiently for land management in areas with competition for land. The analysis of any contemporary debacle in this field needs to take into account specific circumstances, but also account for this inherent difficulty.

\section{REFERENCES}

Amanor, K. (1999). Global restructuring and land rights in Ghana: Forest food chains, timber, and rural livelihoods. Uppsala: Nordiska Afrikainstitutet.

Amanor, K. S. (2008). Sustainable development, corporate accumulation and community expropriation: Land and natural resources in West Africa. In K. S. Amanor, S. Moyo (Eds.), Land and sustainable development in Africa. London: Zed Books.

Amin, S. (1973). Neo-Colonialism in West Africa. New York, London: Monthly Review Press.

Comaroff, J. L., Comaroff, J. (1992). Ethnography and the historical imagination. Boulder: Westview Press.

Cooper, F. (1996). Decolonization and African Society. The Labor Question in French and British Africa. Cambridge: Cambridge University Press.

Cooper, F., Stoler, A. L. (1997). Between Metropole and Colony. In Tensions of empire: Colonial cultures in a bourgeois world. Berkeley: University of California Press.

Falk Moore, S. (1986). Social facts and fabrications "Customary" law on Kilimanjaro, 1880-1980. Cambridge: Cambridge University Press.

Goody, J. (1958). Gold Coast Land Tenure. By R. J. H. Pogucki. Accra: Government Print. Africa, 28(1), 76-78. 
Hill, P. (1997). The migrant cocoa-farmers of Southern Ghana: A study in rural capitalism. Münster: LIT Verlag.

Jackson, J. (1956, August). The Stool Lands Boundaries Settlement - Shai State, Ningo and Prampram. The Gold Coast Gazette (Extraordinary), 1037-1058.

Lentz, C. (2013). Land, mobility, and belonging in West Africa. Bloomington: Indiana University Press.

Pogucki, R. J. (1955). Gold Coast Land Tenure. Accra: Government Printer.

Ranger, T. (1983). The invention of tradition in colonial Africa. In E. Hobsbawm \& T. Ranger (Eds.), The Invention of Tradition. Cambridge: Cambridge University Press.

Rathbone, R. (2000). Nkrumah and the chiefs: The politics of chieftaincy in Ghana, 195160. Athens: Ohio University Press.

Said, E. W. (1994). Culture and imperialism. New York: Vintage Books.

Sarbah, J. M. (2017). Fanti Customary Laws, 1904. London: Forgotten Books.

Scott, J. C. (1998). Seeing like a state: how certain schemes to improve the human condition have failed. New Haven: Yale University Press.

Steedman, C. (2002). Dust: The archive and cultural history. New Brunswick: Rutgers University Press.

Stoler, A. L. (2002). Colonial archives and the arts of governance. Archival Science, 2(1-2), 87-109.

Stoler, A. L. (2009). Along the archival grain: Epistemic anxieties and colonial common sense. Princeton: Princeton University Press.

\section{DOCUMENTS}

Transcript copy of notes in the matter of the Stool Lands Boundaries Settlement order no. 49 of 1950 ;

Transcript copy of notes in the matter of the Stool Lands Boundaries Settlement, Shai order L.N. 195, Prampram order L.N. 434, Ningo order L.N. 159, Public Records and Archives Administration Department (PRAAD), Accra, Ghana. 